\title{
H2S interaction with $\mathrm{Cu}(100)-(22 \times 2) R 45^{\circ}-0$ : Formation of a metastable 0552 sulfur surface reconstruction
}

\author{
Colaianni, M. L.; Syhler, P.; Chorkendorff, Ib
}

Published in:

Physical Review B

Link to article, DOI:

10.1103/PhysRevB.52.2076

Publication date:

1995

Document Version

Publisher's PDF, also known as Version of record

Link back to DTU Orbit

Citation (APA):

Colaianni, M. L., Syhler, P., \& Chorkendorff, I. (1995). H2S interaction with Cu(100)-(2 $2 \times 2)$ R45 $5^{\circ}$-O: Formation of a metastable 05 52sulfur surface reconstruction. Physical Review B, 52(3), 2076-2082.

https://doi.org/10.1103/PhysRevB.52.2076

\section{General rights}

Copyright and moral rights for the publications made accessible in the public portal are retained by the authors and/or other copyright owners and it is a condition of accessing publications that users recognise and abide by the legal requirements associated with these rights.

- Users may download and print one copy of any publication from the public portal for the purpose of private study or research.

- You may not further distribute the material or use it for any profit-making activity or commercial gain

- You may freely distribute the URL identifying the publication in the public portal 


\title{
$\mathrm{H}_{2} \mathrm{~S}$ interaction with $\mathrm{Cu}(\mathbf{1 0 0})-(2 \sqrt{2} \times \sqrt{2}) R 45^{\circ}-\mathrm{O}$ : Formation of a metastable $\left|\begin{array}{ll}5 & 2 \\ 0 & 5\end{array}\right|$-sulfur surface reconstruction
}

\author{
M. L. Colaianni, ${ }^{*}$ P. Syhler, and I. Chorkendorff ${ }^{\dagger}$ \\ Physics Department, Building 307, Technical University of Denmark, DK-2800 Lyngby, Denmark
}

(Received 23 January 1995)

\begin{abstract}
This paper utilizes scanning tunneling microscopy, low-energy electron diffraction, Auger-electron spectroscopy, and temperature-programmed desorption to examine a metastable $\left|{ }_{0}^{5} \frac{2}{5}\right|-S$ structure which forms after the interface reaction of $\mathrm{H}_{2} \mathrm{~S}$ with a $\mathrm{Cu}(100)-(2 \sqrt{2} \times \sqrt{2}) R 45^{\circ}-\mathrm{O}$ surface. This preoxidized copper surface displays an enhanced reactivity towards $\mathrm{H}_{2} \mathrm{~S}$ compared to the clean and annealed $\mathrm{Cu}(100)$ surface. Exposing $15 \mathrm{~L}$ of $\mathrm{H}_{2} \mathrm{~S}$ onto a $\mathrm{Cu}(100)-(2 \sqrt{2} \times \sqrt{2}) R 45^{\circ}$-O surface causes all the adsorbed oxygen to desorb as $\mathrm{H}_{2} \mathrm{O}$ at $164 \mathrm{~K}$, while leaving approximately $0.5 \mathrm{ML}$ of adsorbed sulfur on the surface. When this sulfur overlayer is annealed between 525 and $600 \mathrm{~K}$, a metastable $\mid{ }_{0}^{5} 2 /-\mathrm{S}$ reconstruction forms that is not observed after annealing similar coverages of sulfur adsorbed on an initially clean $\mathrm{Cu}(100)$ surface. Heating the $\left.\right|_{0} ^{52} \mid-\mathrm{S}$ surface to temperatures above $600 \mathrm{~K}$ converts this structure to the thermally stable $\mathrm{Cu}(100)-(\sqrt{17} \times \sqrt{17}) R 14^{\circ}-\mathrm{S}$ (i.e., $\left|\frac{4}{1} 4\right|-\mathrm{S}$ overlayer. A model for the metastable $\left|{ }_{0}^{5} 5_{5}^{2}\right|-\mathrm{S}$ reconstruction is proposed.
\end{abstract}

\section{INTRODUCTION}

An advantage of the scanning tunneling microscope is its ability to examine surface structures with large unit cells, which, due to their complexity, cannot be easily studied by traditional surface-sensitive structural tools. Scanning tunneling microscopy (STM) derives its advantage from its ability to directly image unit cells individually, and in real space, thus negating the complications that arise in diffraction techniques when they are used to measure structures composed of many atoms and/or several domains.

To date, most studies of $\mathrm{H}_{2} \mathrm{~S}$ on preoxidized surfaces have concentrated on the chemistry of the interface. In these studies, $\mathrm{H}_{2} \mathrm{~S}$ reaction with preoxidized surfaces is shown to form water while leaving sulfur on the metal surface. Processes of this nature have been reported on $\mathrm{Pt}(111),{ }^{1} \mathrm{Ni}(110),{ }^{2} \mathrm{Ni}(100),{ }^{3} \mathrm{Cu}(110),{ }^{4,5} \mathrm{Cu}(111),{ }^{6}$ and on $\mathrm{Pb}$ films. ${ }^{7}$ Recently though, the structural aspects of this interface reaction have been examined. Real time studies of $\mathrm{H}_{2} \mathrm{~S}$ exposed onto a preoxidized $\mathrm{Ni}(110)$ surface using STM [Ref. 8(a)] revealed that by dosing $\mathrm{H}_{2} \mathrm{~S}$ onto a preoxidized surface, a $p(4 \times 1)$-S reconstructed layer could be obtained at room temperature, whereas such a structure only formed on the $\mathrm{H}_{2} \mathrm{~S}$-dosed clean $\mathrm{Ni}(110)$ upon annealing to $\geq 473 \mathrm{~K}$. ${ }^{9}$ The reason proposed for this low-temperature formation of the $p(4 \times 1)$ was that a $\mathrm{H}_{2} \mathrm{~S}$ reaction with the $\mathrm{O}$-reconstructed surface produces a rougher surface layer which possesses a higher surface energy than the initially flat metal surface. Such a higher-energy surface facilitates the formation of the $p(4 \times 1)$ structure by reducing the energy barrier for its production. ${ }^{8}$ Very recently similar investigations have been undertaken for the $\mathrm{H}_{2} \mathrm{~S}$ interaction with preoxidized $\mathrm{Cu}(110){ }^{8(\mathrm{~b})}$ The surface is, in effect, preactivated by the oxygen.
This paper studies the chemistry and the structure that result from the reaction of $\mathrm{H}_{2} \mathrm{~S}$ on $\mathrm{Cu}(100)$ $(2 \sqrt{2} \times \sqrt{2}) R 45^{\circ}-O$. We utilize STM, in addition to Auger-electron spectroscopy (AES), low-energy electron diffraction (LEED), and temperature-programmed desorption (TPD) to probe the reaction at this interface, and to examine a metastable sulfur reconstruction on the $\mathrm{Cu}(100)$ surface. This sulfur reconstruction, produced only upon annealing a $\mathrm{H}_{2} \mathrm{~S}$-exposed prereconstructed $\mathrm{Cu}(100)-(2 \sqrt{2} \times \sqrt{2}) R 45^{\circ}$-O layer, has a unit cell structure $\left|\begin{array}{ll}5 & 2 \\ 0 & 5\end{array}\right|$, for which we propose a structural model containing a sulfur coverage of $0.48 \mathrm{ML}$. The well-formed $\left|\begin{array}{ll}5 & 2 \\ 0 & 5\end{array}\right|-\mathrm{S}$ was found to be formed upon annealing a sulfur coverage of $\sim 0.5 \mathrm{ML}$ adsorbed on the $\mathrm{Cu}(100)$ $(2 \sqrt{2} \times \sqrt{2}) R 45^{\circ}-\mathrm{O}$ surface in the temperature range $525-600 \mathrm{~K}$. Above $600 \mathrm{~K}$, the $\left.\right|_{0} ^{5} \frac{2}{5} \mid-\mathrm{S}$ irreversibly converts to the $\left|\frac{4}{1}{ }_{4}^{1}\right|-\mathrm{S}$ structure, ${ }^{10-13}$ which is thermally stable to temperature of at least $1273 \mathrm{~K}$. We propose that the route to the $\left|\begin{array}{ll}5 & 2 \\ 0 & 5\end{array}\right|-S$ structure is enabled by the prereconstruction of the terraces by the adsorbed oxygen of the $\mathrm{Cu}(100)-(2 \sqrt{2} \times \sqrt{2}) R 45^{\circ}$-O surface.

\section{EXPERIMENT}

The experiments reported in this manuscript were performed in a stainless-steel ultrahigh vacuum (UHV) chamber that has been described in detail previously. ${ }^{10}$ Briefly, the chamber houses a single-pass Perkin-Elmer Auger-electron spectrometer, a copper-shielded Balzers QMG 421 C quadrupole mass spectrometer, and a Princeton Research Instruments model 8-120 reverse view LEED apparatus. The principal component in the chamber was a Danish Micro Engineering model 3000 UHV scanning tunneling microscope which we modified to accommodate our custom-designed $\mathrm{Cu}(100)$ crystal holder. The scanning tunneling microscope was operated 
with $0.5-\mathrm{mm} \mathrm{W}$ wire, which was electropolished to a sharp point using the drop-off tip-preparation method. ${ }^{14,15}$

$\mathrm{H}_{2} \mathrm{~S}$ (Linde, 98\% purity) was subjected to two freezepump-thaw cycles prior to use. $\mathrm{O}_{2}$ (Alfax, $99.9995 \%$ purity) was used without further purification. The purity of these gases was verified using a quadrupole mass spectrometer prior to their use. The $\mathrm{Cu}(100)$ crystals used in these studies were spark cut, mechanically polished to a mirrorlike surface, and then electropolished in an $\sim 60 \%$ phosphoric acid at $2 \mathrm{~V}$ for $1-2 \mathrm{~min}$. This final step usually lifted the mirrorlike surface, but LEED and STM analysis confirmed well-ordered surfaces after sputtering and annealing.

\section{RESULTS}

\section{A. $\mathrm{H}_{2} \mathrm{~S}$ reactivity with the $\mathrm{Cu}(100)-(2 \sqrt{2} \times \sqrt{2}) R 45^{\circ}-\mathrm{O}$ surface}

Figure 1 compares Auger uptake curves of $\mathrm{H}_{2} \mathrm{~S}$ exposures onto a clean $\mathrm{Cu}(100)$ surface and a $\mathrm{Cu}(100)$ $(2 \sqrt{2} \times \sqrt{2}) R 45^{\circ}-\mathrm{O}$ surface at $300 \mathrm{~K}$. As is readily apparent, $\mathrm{H}_{2} \mathrm{~S}$ reactivity is enhanced on the preoxidized copper surface relative to the clean copper surface. The initial uptake rate of sulfur is increased on the preoxidized surface, and lower $\mathrm{H}_{2} \mathrm{~S}$ exposures are necessary to achieve a surface-saturated sulfur layer. On the $\mathrm{Cu}(100)$ $(2 \sqrt{2} \times \sqrt{2}) R 45^{\circ}-\mathrm{O}$ surface, $\mathrm{H}_{2} \mathrm{~S}$ exposures of only $30 \mathrm{~L}$ produce a $\mathrm{S}(152 \mathrm{eV}) / \mathrm{Cu}(60 \mathrm{eV})$ ratio close to saturation, $\sim 1.0$, whereas an $\sim 10000 \mathrm{~L}$ exposure of $\mathrm{H}_{2} \mathrm{~S}$ on clean $\mathrm{Cu}(100)$ is required to achieve a similar $\mathrm{S}$ coverage. Furthermore, exposing a $\mathrm{Cu}(100)-(2 \sqrt{2} \times \sqrt{2}) R 45^{\circ}-\mathrm{O}$ surface to $12 \mathrm{~L} \mathrm{H}_{2} \mathrm{~S}$ at room temperature causes a complete replacement of the oxygen on the surface by adsorbed sulfur (Fig. 1).

The sulfur coverage after equivalent exposures onto the clean and $\mathrm{Cu}(100)-(2 \sqrt{2} \times \sqrt{2}) R 45^{\circ}-\mathrm{O}$ surface can be in-

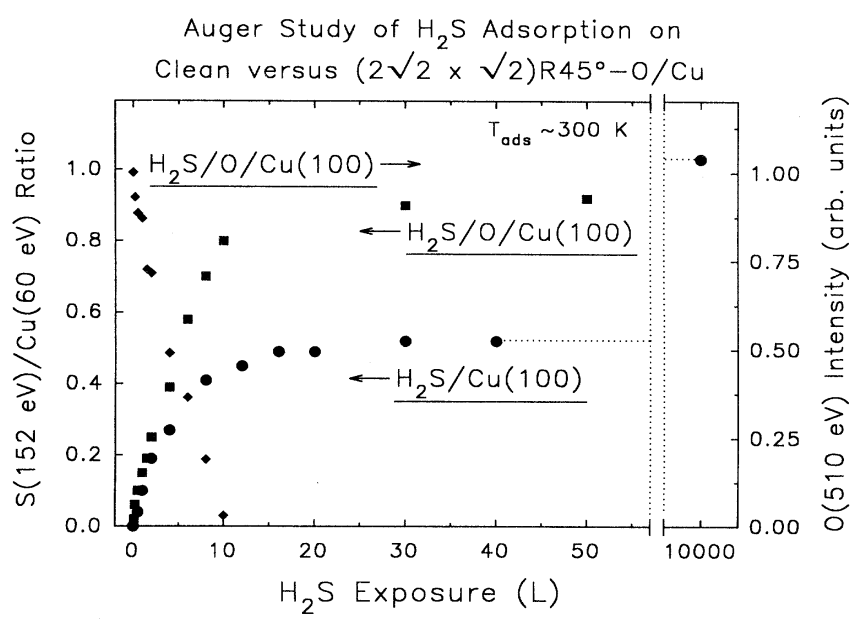

FIG. 1. Sulfur uptake curves comparing the reactivity of $\mathrm{H}_{2} \mathrm{~S}$ on clean and annealed $\mathrm{Cu}(100)$ vs a $\mathrm{Cu}(100)-(2 \sqrt{2} \times \sqrt{2}) R 45^{\circ}-\mathrm{O}$ surface. Also provided is the oxygen attenuation from the $\mathrm{Cu}(100)-(2 \sqrt{2} \times \sqrt{2}) R 45^{\circ}$-O layer as a function of $\mathrm{H}_{2} \mathrm{~S}$ exposure. All adsorbed oxygen is removed by $\mathrm{H}_{2} \mathrm{~S}$ exposures of $>10 \mathrm{~L}$. vestigated by LEED and AES analysis. On the clean surface, a well-ordered $p(2 \times 2)$ surface with only a minimal amount of streaks between the spots ${ }^{16}$ is obtained upon $\mathrm{H}_{2} \mathrm{~S}$ exposures of 8-12 $\mathrm{L}$ followed by a $573-\mathrm{K}$ anneal, suggesting that a $\mathrm{S} / \mathrm{Cu}$ ratio of 0.45 corresponds to a coverage of $\sim 0.25 \mathrm{ML}$. Using this approximation, we determine that a $30-\mathrm{L} \quad \mathrm{H}_{2} \mathrm{~S}$ dose onto the $\mathrm{Cu}(100)$ $(2 \sqrt{2} \times \sqrt{2}) R 45^{\circ}-\mathrm{O}$ surface produces a surface coverage of $\sim 0.5 \mathrm{ML}$, while a $30-\mathrm{L} \mathrm{H}_{2} \mathrm{~S}$ dose on a clean and annealed $\mathrm{Cu}(100)$ surface yields a $\mathrm{S}$ coverage of only $\sim 0.3$ ML.

The process whereby the surface oxygen is removed from the $\mathrm{Cu}(100)-(2 \sqrt{2} \times \sqrt{2}) R 45^{\circ}-\mathrm{O}$ surface and replaced by adsorbed sulfur after dosing with $\mathrm{H}_{2} \mathrm{~S}$ can be studied by TPD as shown in Fig. 2. For this experiment, a $\mathrm{Cu}(100)-(2 \sqrt{2} \times \sqrt{2}) R 45^{\circ}-\mathrm{O}$ layer is prepared and then cooled to $\sim 100 \mathrm{~K}$ prior to a $15-\mathrm{L} \mathrm{H}_{2} \mathrm{~S}$ exposure. Upon heating of this interface, the only desorbing species detected was $\mathrm{H}_{2} \mathrm{O}$ at $164 \mathrm{~K} . \mathrm{H}_{2}$ and $\mathrm{H}_{2} \mathrm{~S}$ were not observed from $\mathrm{H}_{2} \mathrm{~S} / \mathrm{O} / \mathrm{Cu}(100)$ interfaces when the $\mathrm{H}_{2} \mathrm{~S}$ exposures were $\leq 15 \mathrm{~L}$ suggesting that at these exposures all the hydrogen from the adsorbed $\mathrm{H}_{2} \mathrm{~S}$ molecules reacts with the adsorbed oxygen to produce water (Fig. 2).

\section{B. Structure of the sulfided \\ $\mathrm{Cu}(100)-(2 \sqrt{2} \times \sqrt{2}) R 45^{\circ}-\mathrm{O}$ interface}

\section{LEED results}

Figure $3(\mathrm{a})$ shows the $(2 \sqrt{2} \times \sqrt{2}) R 45^{\circ}$-O LEED pattern after oxidizing $\mathrm{Cu}(100)$ with $8000 \mathrm{~L} \mathrm{O}_{2}$ at $500 \mathrm{~K}$. This structure has been studied extensively by LEED, ${ }^{17-19}$ photoelectron diffraction and near-edge $x$ ray absorption fine structure, ${ }^{20}$ x-ray-diffraction, ${ }^{21}$ and STM. ${ }^{22-25}$ All have concluded that a reconstructed missing-row model, possessing an $\mathrm{O}$ coverage of $0.5 \mathrm{ML}$, best describes this surface. In this model, every fourth

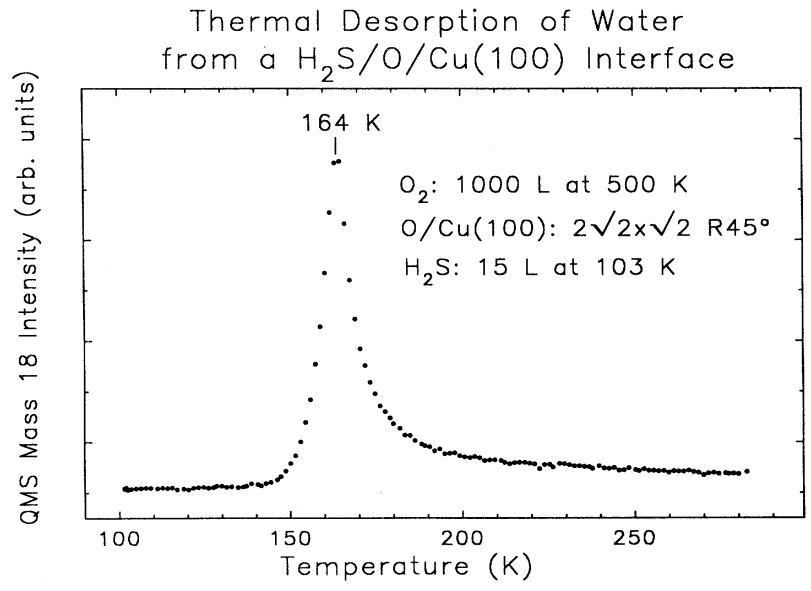

FIG. 2. A temperature-programmed desorption spectrum showing the desorption of water from a $\mathrm{H}_{2} \mathrm{~S} / \mathrm{Cu}(100)$ $(2 \sqrt{2} \times \sqrt{2}) R 45^{\circ}-\mathrm{O}$ interface. The heating rate was $1.0 \mathrm{~K} / \mathrm{s}$. The other masses monitored in this experiment were $2\left(\mathrm{H}_{2}\right), 32$ $\left(\mathrm{O}_{2}, \mathrm{H}_{2} \mathrm{~S}\right), 34\left(\mathrm{H}_{2} \mathrm{~S}\right), 48(\mathrm{SO})$, and $64\left(\mathrm{SO}_{2}\right) \mathrm{amu}$. Only mass 18 was detected. 
row of copper atoms is ejected from the [001] direction into overlayer island structures, while $\mathrm{Cu}-\mathrm{O}$ chains, also in the [001] direction, form in the terraces and on the newly formed islands. ${ }^{23}$ The removal of $\frac{1}{4}$ of the $\mathrm{Cu}(100)$ terrace atoms can be explained to result from adsorbed oxygen overcoordinating electron density to surface copper atoms which causes these atoms to compensate by

\section{(a)}

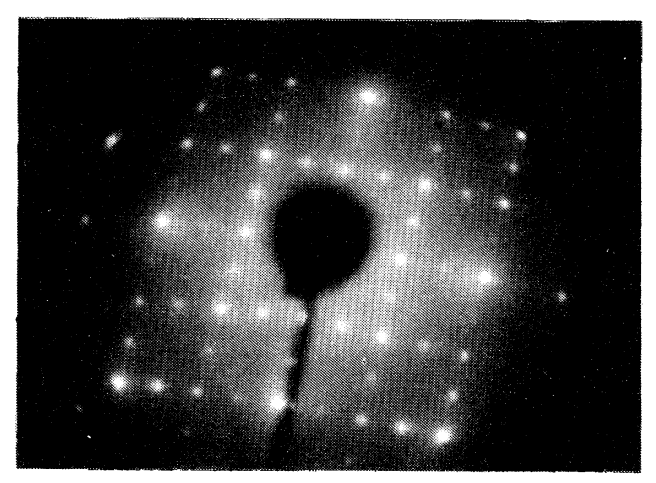

(b)

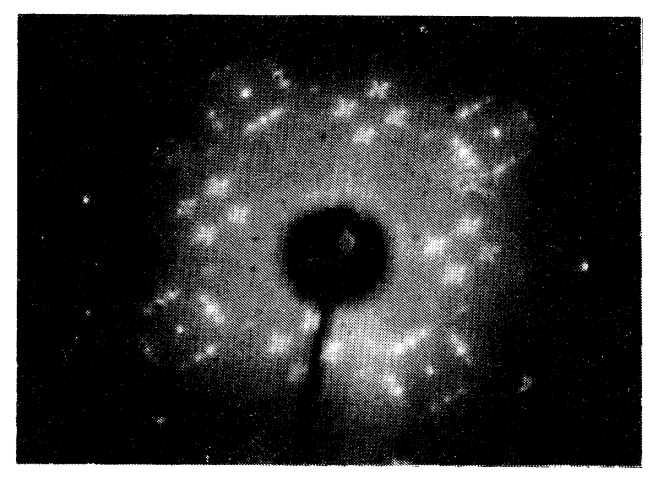

(c)

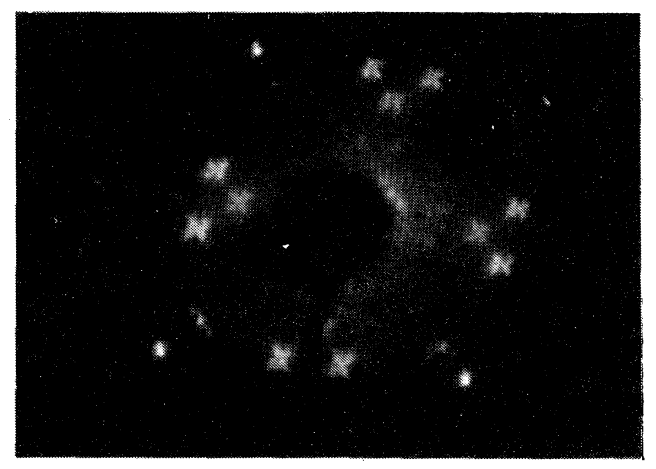

FIG. 3. LEED patterns showing $\mathrm{O}$ - and $\mathrm{S}$-induced reconstructions of $\mathrm{Cu}(100)$ : (a) $\mathrm{A} \mathrm{Cu}(100)-(2 \sqrt{2} \times \sqrt{2}) R 45^{\circ}-\mathrm{O}$ surface prepared by exposing a clean and annealed $\mathrm{Cu}(100)$ to $8000 \mathrm{~L}$ $\mathrm{O}_{2}$ at $500 \mathrm{~K}, E_{p}=194 \mathrm{eV}$; (b) the $\left|\begin{array}{|c|c|}5 & 2 \\ 0 & 5\end{array}\right|-\mathrm{S}$ structure formed by dosing $100 \mathrm{~L} \mathrm{H}_{2} \mathrm{~S}$ on a $\mathrm{Cu}(100)-(2 \sqrt{2} \times \sqrt{2}) R 45^{\circ}$-O surface at $309 \mathrm{~K}$ followed by annealing to $573 \mathrm{~K}, E_{p}=78.6 \mathrm{eV}$, (c) same as (b) except $\mathrm{H}_{2} \mathrm{~S}=10 \mathrm{~L}$ at $105 \mathrm{~K}, E_{p}=50.2 \mathrm{eV}$. reducing their coordination number by moving from within the surface to on top of the surface. ${ }^{26}$ Copper atoms are stabilized in this overlayer arrangement by the stronger $\mathrm{Cu}-\mathrm{O}$ bonds, which form on this reconstructed copper overlayer, compared to the unreconstructed layer. ${ }^{27}$

Exposing this $\mathrm{Cu}(100)-(2 \sqrt{2} \times \sqrt{2}) R 45^{\circ}-\mathrm{O}$ layer to $\geq 10 \mathrm{~L} \mathrm{H}_{2} \mathrm{~S}$ completely removes the ordered LEED pattern, leaving only faint and broad $(1 \times 1)$ spots. However, upon annealing to $575 \mathrm{~K}$, a previously unreported LEED pattern is observed, which is shown in Figs. 3(b) and 3(c). We identify this pattern as resulting from a $\left|\begin{array}{ll}5 & 2 \\ 0 & 5\end{array}\right|$-S surface structure. This surface forms only upon annealing between 525 and $600 \mathrm{~K}$; a sharp LEED pattern is not obtained at temperatures below $525 \mathrm{~K}$, and above $600 \mathrm{~K}$ the $600 \mathrm{~K}$ the structure begins to convert to the $(\sqrt{17} \times \sqrt{17}) R 14^{\circ}-\mathrm{S} / \mathrm{Cu}(100) \quad$ (i.e., $\left|\frac{4}{1} \frac{1}{4}\right|-\mathrm{S}$ structure), which becomes well ordered by further annealing to 675 $\mathrm{K}$. An expanded view of the $\left|\begin{array}{cc}5 & 2 \\ 0 & 5\end{array}\right|$-S LEED structure is shown in Fig. 3(c).

\section{STM results}

STM analysis of the $\left|\begin{array}{ll}5 & 2 \\ 0 & 5\end{array}\right|-S$ structure shows that the surface consists of two domains of zigzagging segments of unit cells [Figs. 4(a) and 4(b)]. When viewed more closely [Fig. 4(c)], these unit cells are observed to contain six clearly resolved protrusions. These protrusions are structurally similar to those observed by us in a previous study of the $\left|\frac{4}{1}{ }_{4}^{1}\right|-\mathrm{S}$ structure on $\mathrm{Cu}(100) .{ }^{10}$ To the best of our ability to measure the interatomic distances, we find the same spacing between neighboring protrusions on the $\left|\begin{array}{ll}5 & 2 \\ 0 & 5\end{array}\right|$-S surface as was measured on the $\left|\frac{4}{1} \frac{1}{4}\right|-S$ surface, specifically, $4.0 \pm 0.15 \AA$. The only difference appears to be the two additional features per unit cell, thus forming heximer instead of tetramer units. The zigzag appearance is produced by $\left|\begin{array}{ll}5 & 2 \\ 0 & 5\end{array}\right|$ and $\left|\begin{array}{ll}5 & \overline{2} \\ 0 & 5\end{array}\right|$ unit cells within each of the domains.

\section{DISCUSSION}

\section{A. Chemistry of $\mathrm{H}_{2} \mathrm{~S}$ adsorption on $\mathrm{Cu}(100)-(2 \sqrt{2} \times \sqrt{2}) R 45^{\circ}-\mathrm{O}$}

\section{Enhanced sulfur uptake}

The sulfidation of $\mathrm{Cu}(100)$ is shown in Fig. 1 to be enhanced by preoxidizing the surface. By monitoring the ratio of the Auger $\mathrm{S}(152 \mathrm{eV}) / \mathrm{Cu}(60 \mathrm{eV})$ peak-to-peak heights as a function of $\mathrm{H}_{2} \mathrm{~S}$ exposure, we measure that the initial $\mathrm{S}$ uptake is increased by as much as a factor of 2 for exposures below $1 \mathrm{~L} \mathrm{H}_{2} \mathrm{~S}$. Also, $\mathrm{H}_{2} \mathrm{~S}$ exposures required to reach saturation differ by approximately two orders of magnitude. Sulfur saturation is achieved by $\leq 100 \mathrm{~L} \mathrm{H}_{2} \mathrm{~S}$ on $\mathrm{Cu}(100)-(2 \sqrt{2} \times \sqrt{2}) R 45^{\circ}-\mathrm{O}$, while $\mathrm{H}_{2} \mathrm{~S}$ exposures of $\sim 10000 \mathrm{~L}$ are needed on the clean and annealed $\mathrm{Cu}(100)$ surface. In both cases, $\mathrm{H}$ blocking of sites for sulfur adsorption is not a factor since adsorbed $\mathbf{H}$ desorbs as $\mathrm{H}_{2}$ on clean $\mathrm{Cu}(100)$ by $300 \mathrm{~K},{ }^{28}$ and as $\mathrm{H}_{2} \mathrm{O}$ on the preoxidized $\mathrm{Cu}(100)$ surface at $164 \mathrm{~K}$.

Auger-electron spectroscopic analysis and thermal 
a)

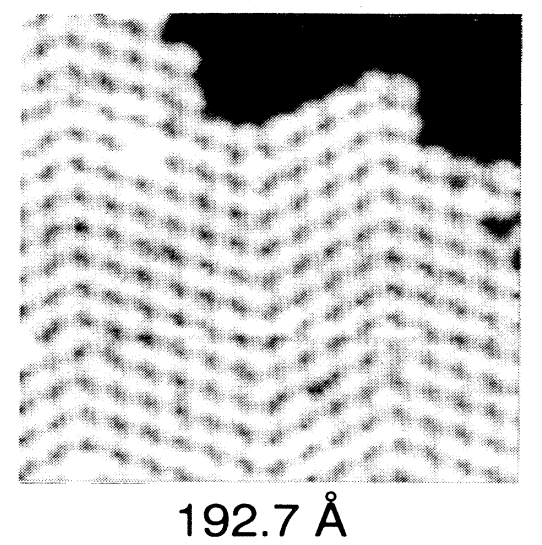

b)

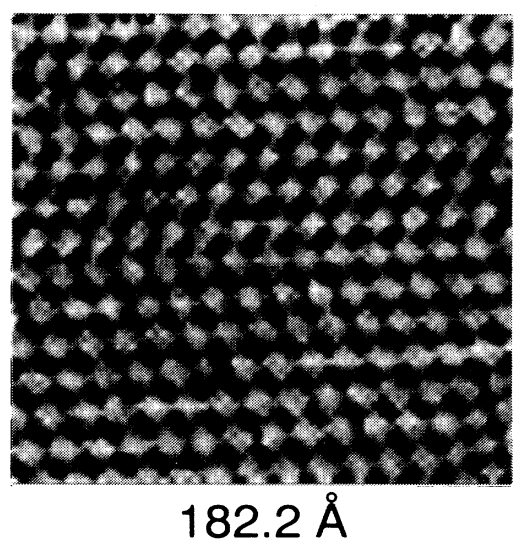

C)

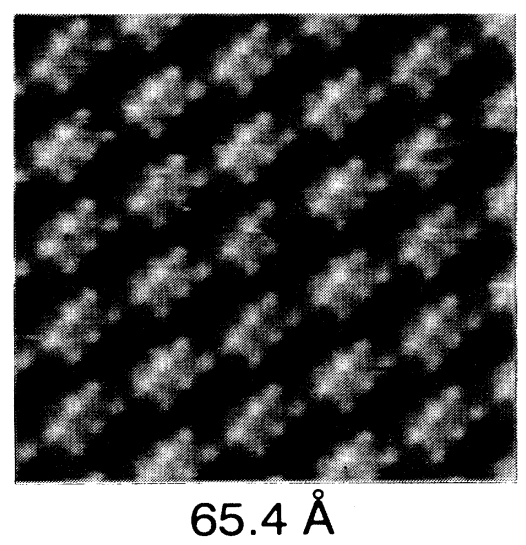

FIG. 4. STM images of the ||$_{0}^{5} 2 \mid-\mathrm{S}$ surface prepared by dosing $100 \mathrm{~L} \mathrm{H}_{2} \mathrm{~S}$ onto $\mathrm{Cu}(100)-(2 \sqrt{2} \times \sqrt{2}) R 45^{\circ}-\mathrm{O}$ at $315 \mathrm{~K}$ followed by annealing to $573 \mathrm{~K}$. All scans were performed with the sample at room temperature. Scan areas, sample bias, and tunneling currents were as follows: (a) $193 \times 193 \AA, V_{b}=0.65 \mathrm{~V}, I_{t}=1.26 \mathrm{nA}$, (b) $182 \times 182 \AA, V_{b}=0.30 \mathrm{~V}, I_{t}=1.06 \mathrm{nA},(\mathrm{c}) 65 \times 65 \AA, V_{b}=0.64 \mathrm{~V}$, $I_{t}=1.26 \mathrm{nA}$.

desorption results reveal that the $\left|\begin{array}{ll}5 & 2 \\ 0 & 5\end{array}\right|-\mathrm{S}$ layer possesses a sulfur coverage approximately equal to the coverage of $\mathrm{O}$ in the $\mathrm{Cu}(100)-(2 \sqrt{2} \times \sqrt{2}) R 45^{\circ}-\mathrm{O}$ surface. The absence of an $\mathrm{H}_{2}$ desorption peak (spectra not shown), as well as the total removal of adsorbed oxygen, as observed by AES, reveals that by dosing the $\mathrm{Cu}(100)$ $(2 \sqrt{2} \times \sqrt{2}) R 45^{\circ}$-O surface with $15 \mathrm{~L} \mathrm{H}_{2} \mathrm{~S}$ at $103 \mathrm{~K}$ (1) all the $\mathrm{H}_{2} \mathrm{~S}$ that is adsorbed loses its $\mathrm{H}$ to the surface oxygen, and (2) the amount of $\mathrm{H}_{2} \mathrm{~S}$ that adsorbs and reacts with the surface is equal to the oxygen coverage of the $\mathrm{Cu}(100)-(2 \sqrt{2} \times \sqrt{2}) R 45^{\circ}-\mathrm{O}$ surface $\left[\Theta_{\mathrm{O}}=0.48 \pm 0.05 \mathrm{ML}\right.$ (Ref. 29)]. A similar observation was made by Huntley upon exposing $\mathrm{H}_{2} \mathrm{~S}$ onto high coverages of oxygen on $\mathrm{Ni}(110){ }^{2}$ This confirms that the $\mathrm{S}$ coverage that forms the $\left|\begin{array}{ll}5 & 2 \\ 0 & 5\end{array}\right|-\mathrm{S}$ structure is similar to that which forms the $\left|\begin{array}{ll}4 & \frac{1}{1}\end{array}\right|$-S structure $\left(\Theta_{\mathrm{S}}=0.47 \mathrm{ML}\right) .^{11}$

Similar to our previous study of the $(\sqrt{17} \times \sqrt{17}) R 14^{\circ}$-S surface, ${ }^{10}$ we find that variations of the sulfur coverage within a range of $\sim 10 \%$ (as judged by AES) did not seem to greatly affect the quality of the $\left|\begin{array}{ll}5 & 2 \\ 0 & 5\end{array}\right|$ LEED pattern, but did affect the annealing temperature required to form the ordered sulfur structure. The $\left|\begin{array}{ll}5 & 2 \\ 0 & 5\end{array}\right|$-S structure was observed after flash annealing the $\mathrm{H}_{2} \mathrm{~S} / \mathrm{Cu}(100)-(2 \sqrt{2} \times \sqrt{2}) R 45^{\circ}-\mathrm{O}$ interface to only $523 \mathrm{~K}$ on surfaces possessing initially high $\mathrm{S}$ coverages, while $573 \mathrm{~K}$ annealing was necessary to form the structure on surfaces with an initial lower $\mathbf{S}$ coverage.

This enhanced reactivity of $\mathrm{H}_{2} \mathrm{~S}$ by preoxidation of the surface is believed to result from the restructured state of the $\mathrm{Cu}(100)$ surface atoms within the $\mathrm{Cu}(100)$ $(2 \sqrt{2} \times \sqrt{2}) R 45^{\circ}$-O structure. In our previous study of $\mathrm{H}_{2} \mathrm{~S} / \mathrm{Cu}(100),{ }^{10}$ STM images recorded during $\mathrm{H}_{2} \mathrm{~S}$ exposure revealed that sulfur coverages above $\sim 0.25 \mathrm{ML}$ adsorb on the $\mathrm{Cu}(100)$ surface via a terrace-restructuring mechanism, where copper atoms were removed from terrace sites while a disordered $\mathrm{Cu}-\mathrm{S}$ overlayer formed. This mechanism allows a sulfur coverage of $\sim 0.5 \mathrm{ML}$ which, after annealing to $900 \mathrm{~K}$, produces an ordered $(\sqrt{17} \times \sqrt{17}) R 14^{\circ}-\mathrm{S}$ structure. ${ }^{10}$ We propose that the enhanced rate of sulfur uptake on the $\mathrm{Cu}(100)$ $(2 \sqrt{2} \times \sqrt{2}) R 45^{\circ}-\mathrm{O}$ surface results from the preremoval of the copper atoms from terrace sites by adsorbed oxygen. This reduces the energy cost of accommodating increased sulfur coverages by eliminating the work required to restructure the $\mathrm{Cu}(100)$ surface. The energy difference between copper in its clean unreconstructed $\mathrm{Cu}(100)$ surface structure and in the reconstructed structure of the $(2 \sqrt{2} \times \sqrt{2}) R 45^{\circ}-\mathrm{O}$ surface has been calculated to be 0.30 eV. ${ }^{25,30}$

\section{Water formation upon $\mathrm{H}_{2} \mathrm{~S}$ adsorption on $\mathrm{Cu}(100)-(2 \sqrt{2} \times \sqrt{2}) \mathrm{R} 45^{\circ}-\mathrm{O}$}

Figure 2 shows that annealing a $\mathrm{H}_{2}$-S-dosed $(2 \sqrt{2} \times \sqrt{2}) R 45^{\circ}-\mathrm{O} / \mathrm{Cu}(100)$ layer at $103 \mathrm{~K}$ with $15 \mathrm{~L}$ $\mathrm{H}_{2} \mathrm{~S}$ produces a $\mathrm{H}_{2} \mathrm{O}$ desorption feature at $164 \mathrm{~K}$. This corresponds closely to the $165-\mathrm{K}$ desorption feature measured by Bange et al. ${ }^{31}$ for the onset of multilayer ice formation on $\mathrm{Cu}(110)$. In their study, monolayer coverages of water were measured to desorb between 167 ad $174 \mathrm{~K}$, while an $-\mathrm{OH}+-\mathrm{OH}$ disproportionation reaction occurred at $290 \mathrm{~K}^{31}$ Similar $\mathrm{H}_{2} \mathrm{O}$ desorption temperatures resulting from molecular desorption and disproportionation reactions have been reported for a large variety of metal surfaces. ${ }^{32}$ The low desorption temperature observed in our studies suggests a weak interaction between the $\mathrm{H}_{2} \mathrm{O}(\mathrm{a})$ and the sulfided surface.

Using solely TPD analysis, we cannot determine the mechanism by which, or the temperature at which, the $\mathrm{H}_{2} \mathrm{O}$ forms on the surface since $\mathrm{H}_{2} \mathrm{O}$ desorbs at the molecular desorption temperature. Remaining unresolved is whether $\mathrm{H}_{2} \mathrm{O}$ forms immediately upon $\mathrm{H}_{2} \mathrm{~S}$ dosing at $103 \mathrm{~K}$, or whether it forms in steps at temperatures above $103 \mathrm{~K}$. Previous studies by Prabhararan, $\mathrm{Sen}$, and $\mathrm{RaO}^{4}$ using high-resolution electron energy loss spectroscopy have shown that $\mathrm{H}_{2} \mathrm{~S} / \mathrm{O} / \mathrm{Cu}(110)$ interfaces 
do not show a $-\mathrm{OH}$ vibrational feature at $80 \mathrm{~K}$, although an $-\mathrm{OH}$ feature is observed upon warming to $120 \mathrm{~K}$. Moroney, Rassias, and Roberts ${ }^{6}$ used x-ray photoemission spectroscopy to show that on an $\mathrm{H}_{2} \mathrm{~S}$ exposed $\mathrm{O} / \mathrm{Cu}(111)$ surface, both $-\mathrm{OH}$ and $\mathrm{H}_{2}-\mathrm{O}$ features are observed at $105 \mathrm{~K}$, but by $136 \mathrm{~K} \mathrm{H}_{2} \mathrm{O}$ is the major component with - $\mathrm{OH}$ existing as a minority species. This adsorbed $\mathrm{H}_{2} \mathrm{O}$ desorbs by $173 \mathrm{~K}$. These papers reveal a pattern of $\mathrm{H}_{2} \mathrm{O}$ forming in steps as the $\mathrm{H}_{2} \mathrm{~S}$ dissociates above $80 \mathrm{~K}$ on the preoxidized copper surfaces. Verification of the exact mechanism on the preoxidized $\mathrm{Cu}(100)$ surface, though, awaits further study. However, we can conclude on the basis of the $\mathrm{H}_{2} \mathrm{O}$ desorption temperature and the absence of any oxygen remaining on the surface at $165 \mathrm{~K}$ that $\mathrm{H}_{2} \mathrm{O}$ formation on this interface does not occur via an $-\mathrm{OH}$ disproportionation reaction.

\section{B. Surface structure after $\mathrm{H}_{2} \mathrm{~S}$ reaction with $\mathrm{Cu}(100)-(2 \sqrt{2} \times \sqrt{2}) R 45^{\circ}-\mathrm{O}$}

Results from LEED, AES, and TPD show clearly that $\mathrm{H}_{2} \mathrm{~S}$ adsorption on the $\mathrm{Cu}(100)-(2 \sqrt{2} \times \sqrt{2}) R 45^{\circ}-\mathrm{O}$ surface at $300 \mathrm{~K}$ results in a disordered overlayer composed solely of $\mathrm{S}$ and $\mathrm{Cu}$. Similarly, disordering of the clean $\mathrm{Cu}(100)$ surface $(1 \times 1)$ structure was observed by STM and LEED after large exposures $(>10000 \mathrm{~L})$ of $\mathrm{H}_{2} \mathrm{~S}$. Evidence for mass transport of the surface metal atoms was provided by STM, which observed flat (100) terraces transform into crevasses and islands supporting chainlike structures. In similar studies, STM analysis during $\mathrm{H}_{2} \mathrm{~S}$ reaction with the $\mathrm{O} / \mathrm{Cu}(100)$ surface has also shown mass transport of $\mathrm{Cu}$ on the surface resulting in the formation of large island structures. ${ }^{8(b)}$ In this study, however, a STM analysis of the disordering process on the $\mathrm{Cu}(100)$ $(2 \sqrt{2} \times \sqrt{2}) R 45^{\circ}$-O interface was not performed. The removal of the LEED pattern upon $\mathrm{H}_{2} \mathrm{~S}$ adsorption though reveals that a disordering process also occurs at the oxidized interface. While the mechanistic details of this disordering are not known, a model involving $\mathrm{Cu}$ mass transport as observed on the clean $\mathrm{Cu}(100)$ surface $^{10}$ and the preoxidized $\mathrm{Cu}(110)$ surface $^{8(\mathrm{~b})}$ is believed to be occurring.

Upon warming to $373 \mathrm{~K}$, the LEED pattern shows large broad spots where the four-point features appear on the LEED pattern of the well-formed $\left|\begin{array}{ll}5 & 2 \\ 0 & 2\end{array}\right|$-S surface. Similar broad features were always observed after annealing larger doses (10000 L) of $\mathrm{H}_{2} \mathrm{~S}$ onto the clean $\mathrm{Cu}(100)$ surface. Careful annealing of this $\mathrm{H}_{2} \mathrm{~S} / \mathrm{Cu}(100)$ interface produced only these broad spots until the $\left|\frac{4}{1}{ }_{4}^{1}\right|-S$ formed at $\sim 973 \mathrm{~K} .{ }^{10}$ In addition, experiments which used a line-of-sight heated filament during $\mathrm{H}_{2} \mathrm{~S}$ dosing to deposit sulfur coverages $\geq 0.5 \mathrm{ML}$ also failed to yield the $\left|\begin{array}{ll}5 & 2 \\ 0 & 5\end{array}\right|-\mathrm{S}$ structure after annealing, despite the necessary quantity of adsorbed sulfur on the surface. Only by sulfiding a $\mathrm{Cu}(100)-(2 \sqrt{2} \times \sqrt{2}) R 45^{\circ}-\mathrm{O}$ layer could the well-ordered $\left|\begin{array}{|c|c|c|}5 & 2 \\ 0 & 5\end{array}\right|$-S structure be formed prior to the $\left|\frac{4}{1} \frac{1}{4}\right|-\mathrm{S}$.

These observations lead us to propose that the ordered metastable $\left|\begin{array}{ll}5 & 2 \\ 0 & 5\end{array}\right|-S$ structure must involve a large kinetic barrier to formation on the clean $\mathrm{Cu}(100)$ surface, requiring temperatures beyond those which cause the onset of the thermodynamically stable $\left|\frac{4}{1} \frac{1}{4}\right|-\mathrm{S}$ structure. Therefore, the ordered $\left|\begin{array}{ll}5 & 2 \\ 0 & 5\end{array}\right|-S$ overlayer is not observed from the clean surface. However, beginning with a reconstructed $\mathrm{Cu}(100)-(2 \sqrt{2} \times \sqrt{2}) R 45^{\circ}-\mathrm{O}$ surface, the barrier to formation of the $\left|\begin{array}{ll}5 & 2 \\ 0 & 5\end{array}\right|-\mathrm{S}$ is lowered to become accessible at $525 \mathrm{~K}$. This is believed to result from the O-induced restructuring of the copper atoms from the flat (100) surface to the higher-energy $\mathrm{Cu}(100)-(2 \sqrt{2} \times \sqrt{2}) R 45^{\circ}-\mathrm{O}$ structure. ${ }^{27}$ From this higher-energy starting point, the barrier to formation of the $\left|\begin{array}{ll}5 & 2 \\ 0 & 5\end{array}\right|-\mathrm{S}$ is lower and becomes accessible prior to the onset of the $\left|\frac{4}{1} \frac{1}{4}\right|-\mathrm{S}$.

The most obvious feature of the $\left|\begin{array}{ll}5 & 2 \\ 0 & 5\end{array}\right|-S$ is its herringlike structure. This results from alternating chains of $\left|\begin{array}{ll}5 & 2 \\ 0 & 5\end{array}\right|$ and $\left|\begin{array}{ll}5 & 0 \\ 2 & 5\end{array}\right|$ unit cells. These chains vary between 1 and 10 unit cells in length, with lengths between 4 and 6 unit cells being the most common. This preference suggests that a structural strain is inherent within the overlayer structure, since a strain-free layer should display either (1) one orientation only, if attractive interactions existed between the cells, or (2) purely random orderings of $\left|\begin{array}{ll}5 & 2 \\ 0 & 5\end{array}\right|$ and $\left|\begin{array}{cc}5 & 0 \\ 2 & 5\end{array}\right|$ unit cells, if attractive interactions did not exist between the unit cells. These purely random orderings would display a probability $\boldsymbol{P}$ of chains to form of given length $n$ to follow the form $P=2\left(\frac{1}{2}\right)^{n}$, which would favor very short chain lengths.

Such a favoring of very short chain lengths or of the one-orientation domains is not observed. Instead, it appears that unit cells stabilize neighboring cells of the same orientation, and thus grow in finite lengths of one orientation, but that a strain associated with possessing solely one orientation on the copper substrate increases with increasing chain length - since very long chains are not favored. Thus the zigzag pattern reduces the strain within the $\left|\begin{array}{ll}5 & 2 \\ 0 & 5\end{array}\right|-S$ overlayer, but it apparently does not cause it to be as stable as the $\left|\frac{4}{1}{ }_{4}^{1}\right|-\mathrm{S}$, to which the $\left|\begin{array}{ll}5 & 2 \\ 0 & 5\end{array}\right|-\mathrm{S}$ converts upon warming to $573 \mathrm{~K}$. Therefore, the $\left|\begin{array}{ll}5 & 2 \\ 0 & 5\end{array}\right|-\mathrm{S}$ is observed only as a metastable surface structure.

The $\left|\begin{array}{ll}5 & 2 \\ 0 & 5\end{array}\right|-S$ unit cell is shown by STM to be composed of six resolved protrusions. These protrusions are believed to result from adsorbed sulfur. This is based, in part, on the calculations performed by Lang, ${ }^{33}$ who shows for tip biases below $\sim 1.3 \mathrm{~V}$ that an adsorbed $\mathrm{S}$ adds to the density of states in this energy range, and therefore is imaged as a protrusion. In addition, numerous STM studies of $\mathbf{S}$ adsorption on a variety of metal surfaces have assigned the protrusions resolved in their images to sulfur. These surfaces include $\mathrm{Cu}(111),{ }^{34}$ $\mathrm{Cu}(110),{ }^{35} \mathrm{Cu}(11,1,1),{ }^{36} \mathrm{Ni}(111),{ }^{26} \mathrm{Ni}(110),{ }^{9,37}$ $\operatorname{Re}(0001),{ }^{38,39} \operatorname{Pd}(111),{ }^{40} \operatorname{Pd}(100),{ }^{41}$ and $\mathrm{Mo}(100) .{ }^{42}$ Finally, our own STM studies of the $p(2 \times 2)$-S overlayer gave protrusion at interatomic $2 a_{0}$ distances.

Our model proposed for the $\left|\begin{array}{ll}5 & 2 \\ 0 & 5\end{array}\right|-S$ structure, shown in Fig. 5, contains 12 sulfur atoms, for a sulfur coverage of 0.48 , in accord with our AES and TPD results. Since only six features per unit cell are imaged, the surface is postulated to contain two types of sulfur atoms. The six resolved sulfur atoms are assigned to pseudo-fourfoldhollow sites (FFHS) on the top copper layer. These sites are chosen since surface sulfur should readily be imaged by STM [as in the $p(2 \times 2)$ layer] and since sulfur favors 


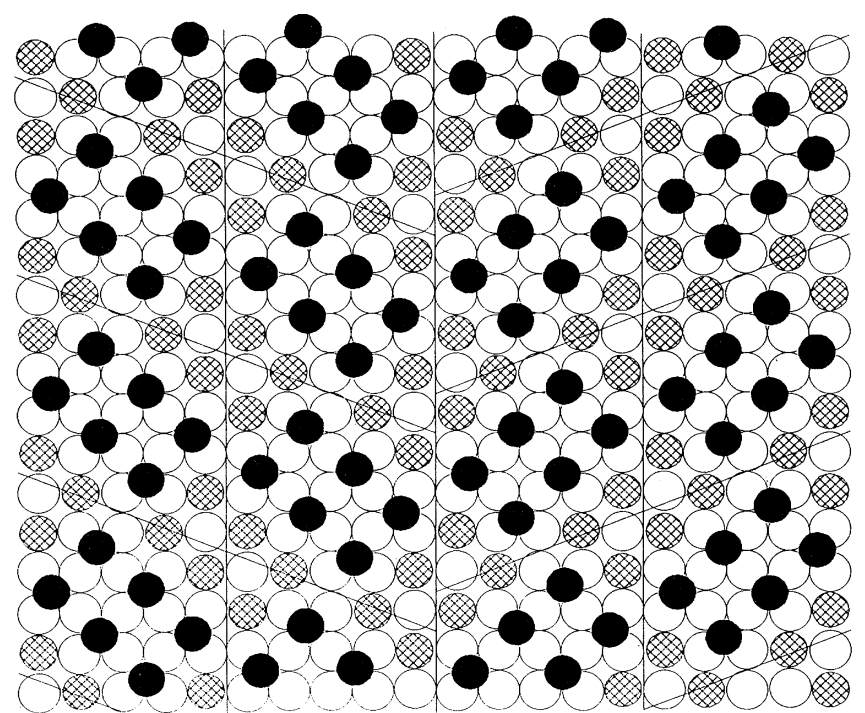

FIG. 5. Model of the $\left|{ }_{0}^{5}{ }_{5}^{2}\right|-S$ structure. Black filled circles represent surface sulfur atoms in pseudo-FFHS, crossedhatched circles represent in-plane sulfur atoms which substitute for copper atoms in the surface layer, and the white circles represent copper atoms. The unit cells of one domain are shown. Equivalent $\left|\begin{array}{ll}5 & 2 \\ 0 & 5\end{array}\right|$ and $\left|\begin{array}{ll}5 & 0 \\ 2 & 5\end{array}\right|$ unit cells are shown to produce the zig-zag pattern observed. See text for details.

sites of high coordination. Additionally, these are the sites on the copper surface that most closely allow for the measured sulfur interatomic separation of $4.0 \pm 0.15 \AA$. While the unreconstructed $\sqrt{2} a_{0}$ sites are only $3.6 \AA$ apart, distortions within the top layer are proposed to cause this increased S-S separation. This is consistent with the observed herring-row structure, which will release some of the stress built up by this expansion.

The regions of the surface which are imaged as depressions are proposed to contain the remaining six sulfur atoms of the unit cell. These sulfur atoms are proposed to occupy sites within the top copper layer, replacing copper atoms in the surface plane. These sulfur atoms will be referred to as in-plane sulfur atoms. While there is no direct evidence for the positions assigned to the inplane sulfur atoms, such sites are reasonable for the following reasons: (1) high coverages of sulfur are known to reconstruct the top copper layer by removing copper atoms from terrace sites ${ }^{10}$ - and these empty sites should be ideal for sulfur, which always bonds most favorably in sites of high coordination; (2) the interatomic repulsion between adsorbed sulfur atoms will tend to drive the sulfur atoms as far apart as possible, which is only possible by placing sulfur atoms in the regions imaged as depressions; and (3) the S-Cu bond lengths in covellite, CuS $\left[d_{\text {CuS }}=2.19-2.33 \AA\right]$ (Ref. 43) and other Cu-S compounds $\left(d_{\mathrm{CuS}}=2.16-2.33 \AA\right.$ ) (Ref. 44$)$ are shorter than the bulk $\mathrm{Cu}-\mathrm{Cu}$ bond length $(2.55 \AA)$. Therefore, these in-plane sulfur atoms would be expected to cause an inward repositioning of their neighboring copper atoms. These copper atoms make up the FFHS which adsorb the surface sulfur atoms. Consequently, this distorts the FFHS and allows the sulfur atoms in these FFHS to expand their interatomic distances, as the images indicate. This model is similar to one proposed by us in an earlier study of the $\left|\frac{4}{1}{ }_{4}^{1}\right|-S$ surface. ${ }^{10}$ Additional details of the $\mathrm{S} / \mathrm{Cu}(100)$ interface are contained therein.

\section{CONCLUSION}

This paper centers around the discovery of a metastable sulfur structure with a unit cell $\left|\begin{array}{ll}5 & 2 \\ 0 & 5\end{array}\right|$, which forms upon dosing $\mathrm{H}_{2} \mathrm{~S}$ onto a $\mathrm{Cu}(100)-(2 \sqrt{2} \times \sqrt{2}) R 45^{\circ}-\mathrm{O}$ surface. This sulfur structure and the reaction that produces it have been characterized by the complementary techniques of LEED, STM, TPD, and AES. We arrive at the following conclusions: (1) Sulfur uptake from $\mathrm{H}_{2} \mathrm{~S}$ adsorption is enhanced on a $\mathrm{Cu}(100)-(2 \sqrt{2} \times \sqrt{2}) R 45^{\circ}-\mathrm{O}$ surface compared to the clean and annealed $\mathrm{Cu}(100)$ surface. (2) $\mathrm{H}_{2} \mathrm{~S}$ dissociatively adsorbs on the $\mathrm{Cu}(100)$ $(2 \sqrt{2} \times \sqrt{2}) R 45^{\circ}-\mathrm{O}$ surface, causing water formation and desorption by $164 \mathrm{~K}$, and forming a disordered coppersulfur overlayer. $\mathrm{H}_{2} \mathrm{~S}$ exposures between 10 and $100 \mathrm{~L}$ leave a sulfur coverage of $\sim 0.5 \mathrm{ML}$. (3) Annealing this disordered copper-sulfur layer to temperatures between 525 and $600 \mathrm{~K}$ produces an ordered $\left|\begin{array}{ll}5 & 2 \\ 0 & 5\end{array}\right|-\mathrm{S}$ metastable surface. (4) Continued annealing to, or above, $600 \mathrm{~K}$ causes the $\left|\begin{array}{ll}5 & 2 \\ 0 & 5\end{array}\right|-\mathrm{S}$ structure to convert to a $\left|\frac{4}{1}{ }_{4}^{1}\right|-\mathrm{S}$ overlayer. (5) A model for the $\left|\begin{array}{ll}5 & 2 \\ 0 & 5\end{array}\right|$ structure consisting of 12 sulfur atoms per 25 -atom $\mathrm{Cu}$ unit cell is proposed. This model proposes two types of adsorbed sulfur, six surfacesulfur atoms located in pseudo fourfold-hollow sites, and six in-plane sulfur atoms occupying $\mathrm{Cu}$ atom sites within the top copper layer.

\section{ACKNOWLEDGMENT}

We would like to gratefully acknowledge support for this work by the Danish Research Council through the "Center for Surface Reactivity."
*Present address: Exxon Research and Engineering Company, Corporate Research, Route 22 East, Annandale, NJ 08801.

${ }^{\dagger}$ Author to whom correspondence should be addressed.

${ }^{1}$ G. E. Mitchell, M. A. Schulz, and J. M. White, Surf. Sci. 197, 379 (1988).

${ }^{2}$ D. R. Huntley, Surf. Sci. 240, 24 (1990).

${ }^{3}$ Y. Zhou and J. M. White, Surf. Sci. 183, 363 (1987).

${ }^{4}$ K. Prabhararan, P. Sen, and C. N. R. Rao, Surf. Sci. 169, L301 (1986).
${ }^{5}$ P. S. Uy, J. Bardolle, and M. Bujor, Surf. Sci. 134, 713 (1983).

${ }^{6}$ L. Moroney, S. Rassis, and M. W. Roberts, Surf. Sci. 105, L249 (1981).

${ }^{7}$ K. Kishi and M. W. Roberts, J. Chem. Soc. Faraday Trans. I 71, 1721 (1975).

${ }^{8}$ (a) L. Ruan, F. Besenbacher, I. Stensgaard, and E. Laegsgaard, Phys. Rev. Lett. 69, 3523 (1992); (b) F. Besenbacher, P. T. Sprunger, L. Ruan, L. Olesen, I. Stensgaard, and E. Laegsgaard, Topics Catal. 1, 325 (1994). 
${ }^{9}$ F. Besenbacher, I. Stensgaard, L. Ruan, J. K. Nørskov, and K. W. Jacobsen, Surf. Sci. 272, 334 (1992).

${ }^{10}$ M. L. Colaianni and I. Chorkendorff, Phys. Rev. B 50, 8798 (1994).

${ }^{11}$ J. L. Domange and J. Oudar, Surf. Sci. 11, 124 (1968).

${ }^{12}$ V. Maurice, J. J. Legendre, and M. Huber, Surf. Sci. 129, 312 (1983).

${ }^{13}$ M. Huber and J. Oudar, Surf. Sci. 47, 605 (1975).

${ }^{14}$ J. P. Song, N. H. Pryds, K. Glejbøl, K. A. Mørch, A. R. Thölén, and L. N. Christensen, Rev. Sci. Instrum. 64, 900 (1993).

${ }^{15}$ H. Lemke, T. Goddenhenrich, H. P. Bochem, U. Hartmann, and C. Heiden, Rev. Sci. Instrum. 61, 2538 (1990).

${ }^{16}$ H. C. Zeng and K. A. R. Mitchell, Can. J. Phys. 65, 500 (1987).

${ }^{17}$ H. C. Zeng, R. A. McFarlane, and K. A. R. Mitchell, Surf. Sci. 208, L7 (1989).

${ }^{18}$ H. C. Zeng and K. A. R. Mitchell, Surf. Sci. 239, L571 (1990).

${ }^{19}$ M. Sotto, Surf. Sci. 260, 235 (1992).

${ }^{20}$ M. C. Asensio, M. J. Ashwin, A. L. D. Kilcoyne, D. P. Woodruff, A. W. Robinson, Th. Lindner, J. S. Somers, D. E. Richen, and A. M. Bradshaw, Surf. Sci. 236, 1 (1990).

${ }^{21}$ I. K. Robinson, E. Vlieg, and S. Ferrer, Phys. Rev. B 42, 6954 (1990).

${ }^{22}$ Ch. Wöll, R. J. Wilson, S. Chiang, H. C. Zeng, and K. A. R. Mitchell, Phys. Rev. B 42, 11926 (1990).

${ }^{23}$ F. Jensen, F. Besenbacher, E. Laegsgaard, and I. Stensgaard, Phys. Rev. B 42, 9206 (1990).

${ }^{24}$ F. Besenbacher and I. Stensgaard, in The Chemical Physics of Solid Surfaces and Heterogeneous Catalysis, edited by D. A. King and D. P. Woodruff (Elsevier, New York, 1993), Vol. 7, Chap. 15.

${ }^{25}$ F. Besenbacher and J. K. Nørskov, Prog. Surf. Sci. 44, 5 (1993).

${ }^{26}$ L. Ruan, I. Stensgaard, F. Besenbacher, and E. Laegsgaard,
Phys. Rev. Lett. 71, 2963 (1993).

${ }^{27}$ K. W. Jacobsen and J. K. Nørskov, Phys. Rev. Lett. 65, 1788 (1990).

28I. Chorkendorff and P. B. Rasmussen, Surf. Sci. 248, 35 (1991).

${ }^{29}$ M. Wuttig, R. Franchy, and H. Ibach, Surf. Sci. 213, 103 (1989).

30J. K. Nørskov, Rep. Prog. Phys. 53, 1253 (1990).

${ }^{31}$ K. Bange, D. E. Grider, T. E. Madey, and J. K. Sass, Surf. Sci. 136, 38 (1984).

32P. A. Thiel and T. E. Madey, Surf. Sci. Rep. 7, 211 (1987).

${ }^{33}$ N. D. Lang, Phys. Rev. Lett. 58, 45 (1987).

${ }^{34}$ L. Ruan, I. Stensgaard, F. Besenbacher, and E. Laegsgaard, Ultramicroscopy 42-44, 498 (1992).

${ }^{35}$ I. Stensgaard, L. Ruan, F. Besenbacher, F. Jensen, and E. Laegsgaard, Surf. Sci. 269/270, 81 (1992).

${ }^{36}$ S. Rousset, S. Gauthier, O. Siboulet, W. Sacks, M. Belin, and J. Klein, Phys. Rev. Lett. 63, 1265 (1989).

${ }^{37}$ L. Ruan, I. Stensgaard, E. Laegsgaard, and F. Besenbacher, Surf. Sci. 296, 275 (1993).

${ }^{38}$ D. F. Ogletree, C. Ocal, B. Marchon, G. A. Somorjai, M. Salmeron, T. Beebe, and W. Siekhaus, J. Vac. Sci. Technol. A 8, 297 (1990).

${ }^{39}$ D. F. Ogletree, R. Q. Hwang, D. M. Zeglinski, A. Lopez Vazquez-de-Parga, G. A. Somorjai, and M. Salmeron, J. Vac. Sci. Technol. B 9, 886 (1991).

${ }^{40}$ J. G. Forbes, A. J. Gellman, J. C. Dunphy, and M. Salmeron, Surf. Sci. 279, 68 (1992).

${ }^{41}$ D. Bürgler, G. Tarrach, T. Schaub, R. Wiesendanger, and H.J. Güntherodt, Phys. Rev. B 47, 9963 (1993).

${ }^{42}$ B. Marchon, P. Bernhardt, M. E. Bussell, G. A. Somorjai, M. Salmeron, and W. Siekhaus, Phys. Rev. Lett. 60, 1166 (1988).

${ }^{43}$ H. Fjellvåg, F. Grønvold, Stølen, A. F. Andresen, R. MüllerKäfer and A. Simon, Z. Kristallogr. 184, 111 (1988).

${ }^{44}$ I. G. Dance, Aust. J. Chem. 31, 2195 (1978). 
(a)

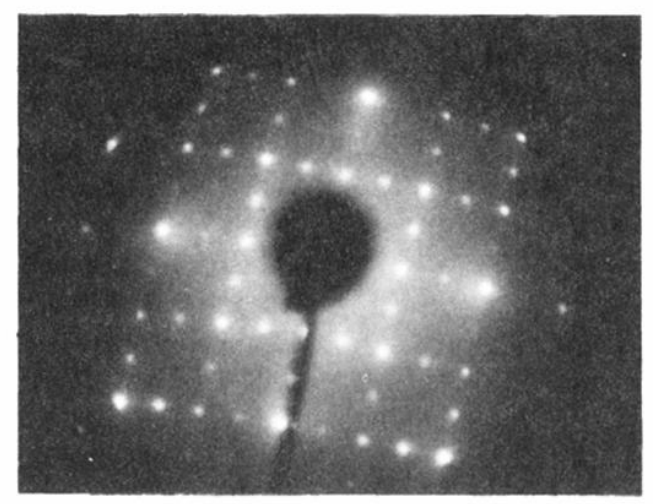

(b)

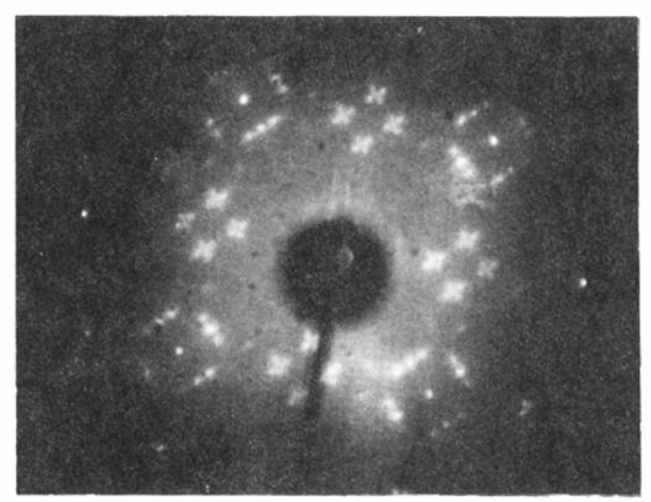

(c)

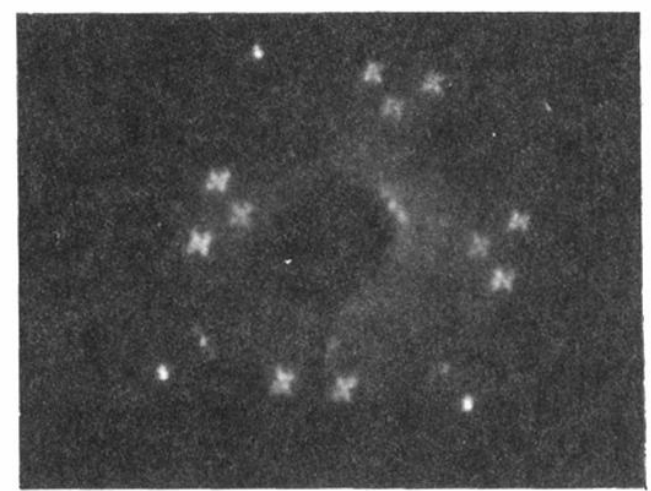

FIG. 3. LEED patterns showing O- and S-induced reconstructions of $\mathrm{Cu}(100)$ : (a) $\mathrm{A} \mathrm{Cu}(100)-(2 \sqrt{2} \times \sqrt{2}) R 45^{\circ}-\mathrm{O}$ surface prepared by exposing a clean and annealed $\mathrm{Cu}(100)$ to $8000 \mathrm{~L}$ $\mathrm{O}_{2}$ at $500 \mathrm{~K}, E_{p}=194 \mathrm{eV}$; (b) the $\left.\right|_{0} ^{5}{ }_{5}^{2} \mid-\mathrm{S}$ structure formed by dosing $100 \mathrm{~L} \mathrm{H}_{2} \mathrm{~S}$ on a $\mathrm{Cu}(100)-(2 \sqrt{2} \times \sqrt{2}) R 45^{\circ}-\mathrm{O}$ surface at $309 \mathrm{~K}$ followed by annealing to $573 \mathrm{~K}, E_{p}=78.6 \mathrm{eV}$, (c) same as (b) except $\mathrm{H}_{2} \mathrm{~S}=10 \mathrm{~L}$ at $105 \mathrm{~K}, E_{p}=50.2 \mathrm{eV}$. 
a)

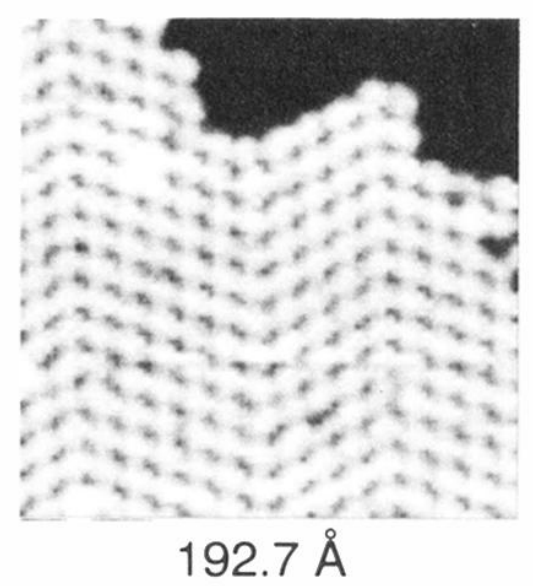

b)

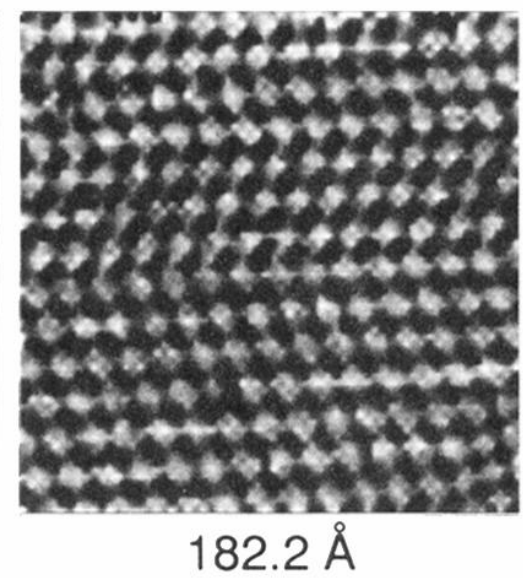

c)

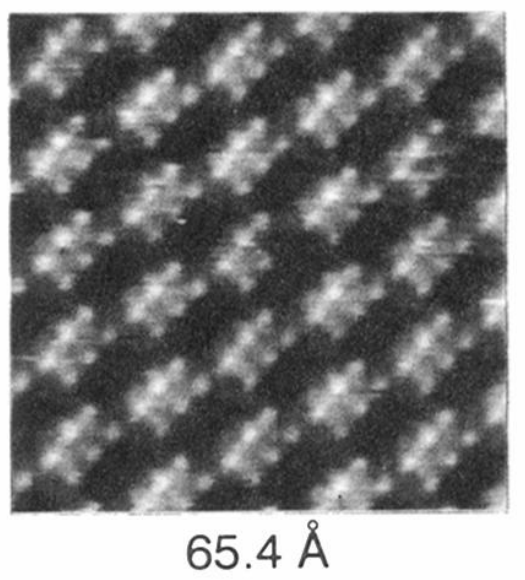

FIG. 4. STM images of the $\left|\begin{array}{ll}5 & 2\end{array}\right|-\mathrm{S}$ surface prepared by dosing $100 \mathrm{~L} \mathrm{H}_{2} \mathrm{~S}$ onto $\mathrm{Cu}(100)-(2 \sqrt{2} \times \sqrt{2}) R 45^{\circ}-\mathrm{O}$ at $315 \mathrm{~K}$ followed by annealing to $573 \mathrm{~K}$. All scans were performed with the sample at room temperature. Scan areas, sample bias, and tunneling currents were as follows: (a) $193 \times 193 \AA, V_{b}=0.65 \mathrm{~V}, I_{t}=1.26 \mathrm{nA}$, (b) $182 \times 182 \AA, V_{b}=0.30 \mathrm{~V}, I_{t}=1.06 \mathrm{nA},(\mathrm{c}) 65 \times 65 \AA, V_{b}=0.64 \mathrm{~V}$, $I_{t}=1.26 \mathrm{nA}$. 